\title{
Socio-economic assessment on maize production and adoption of open pollinated improved varieties in Dang, Nepal
}

\author{
Sanjiv Subedi*, Yuga Nath Ghimire and Deepa Devkota \\ Government of Nepal, Nepal Agricultural Research Council, Socioeconomics \\ and Agricultural Research Policy Division, Khumaltar, Lalitpur, Nepal \\ *Corresponding author email: sanjiv.subedi@gmail.com \\ ORCID ID: https://orcid.org/0000-0002-8084-008X
}

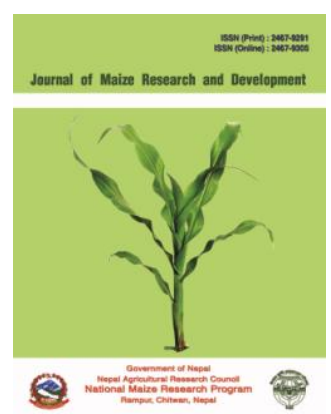

Received: June 23, 2017; Revised: September 21, 2017; Accepted: November 12, 2017

(c) Copyright 2017 Subedi et al .

(c) (1) (9)

This work is licensed under a Creative Commons Attribution-NonCommercial 4.0 International License.

\begin{abstract}
Research was conducted from February to May, 2017 for socioeconomic assessment on maize production and adoption of open pollinated improved maize varieties in Dang district of Nepal. Altogether, 100 samples were taken by simple random sampling from the major maize growing areas and relevant publications were reviewed. Focal Group Discussion and Key Informant Survey were also done. Descriptive statistics, unpaired t-test, probit regression and indexing were used for data analysis using statistical tools- SPSS, STATA and MS-Excel. Probit econometric model revealed that ethnicity ( $1 \%$ level), gender ( $5 \%$ level), area under open pollinated improved maize ( $1 \%$ level), seed source dummy ( $1 \%$ level) and number of visits by farmers to agrovet (5\% level) significantly determined the adoption of open pollinated improved maize varieties. In addition, unpaired t-test revealed that the productivity of open pollinated improved maize varieties was significantly higher (at $1 \%$ level) than local; also, the multinational companies' hybrids showed significantly higher productivity (at $1 \%$ level) when compared to open pollinated improved varieties. Furthermore, indexing identified- lack of availability of quality seeds and fertilizers ( $I=0.86)$ as the major problem associated with the maize production. Giving aggressive subsidy on open pollinated improved seeds and dealership to registered agrovets for selling the subsidy seeds could enhance the adoption. Moreover, government organizations working in the areas of agricultural extension and research must focus on adoption of open pollinated improved maize varieties among the farmers, substituting the local and developing the high yielding hybrid varieties in Nepal to increase the maize productivity.
\end{abstract}

Keywords: Adoption, maize productivity, probit regression, socioeconomic assessment

Correct citation: Subedi, S., Ghimire, Y. N., \& Devkota, D. (2017). Socio-economic assessment on maize production and adoption of open pollinated improved varieties in Dang, Nepal. Journal of Maize Research and Development, 3 (1), 17-27. doi: http://dx.doi.org/10.3126/jmrd.v3i1.18916 


\section{INTRODUCTION}

In Nepal, agriculture and forestry sector contributed $31.13 \%$ share to the national Gross Domestic Product (GDP). Maize (891583 ha) is the second most important crop in Nepalese agriculture after rice (1362908 ha) in terms of area. The total maize production and yield of maize have been reported $2231517 \mathrm{t}$ and $2.50 \mathrm{t} / \mathrm{ha}$ in Nepal; $53043 \mathrm{t}$. and $2.3 \mathrm{t} / \mathrm{ha}$ in Dang respectively (MOAD, 2017). It would be a wise decision to adopt open pollinated (OP) improved varieties as it yields higher compared to local; also, unlike hybrids, the seeds of open pollinated varieties could be kept for next year. More than 20 open pollinated improved varieties of maize including Poshilo Makai-1 (recommended in 2008 for mid-hills below $1600 \mathrm{~m}$ ) and few hybrids: Gaurav (recommended in 2003), Rampur hybrid 4 (recommended in 2016) have been developed by National Maize Research Program (NMRP), Chitwan, Nepal.

The total area, production and yield of improved maize in Nepal have been reported 841596 ha, $2143824 \mathrm{t}$ and $2.55 \mathrm{t} / \mathrm{ha}$ respectively (MOAD, 2017). In Dang, the total area, production and yield of open pollinated improved maize varieties have been reported $16730 \mathrm{ha}, 35133 \mathrm{t}$ and $2.1 \mathrm{t} /$ ha respectively. Also, $17 \mathrm{t}$ seeds of open pollinated improved maize varieties have been sold from DADO, Dang with 50\% subsidy in the fiscal year 2016/17 (DADO, 2017). Prime Minister Agriculture Modernization Project (PM-AMP) has selected Dang as 'maize superzone' (MOAD, 2016). Rampur Composite (recommended in 1975 for terai and mid hills), Arun 2 (recommended in 1981 for terai and mid-hills) are the commonly grown open pollinated improved varieties in Dang (DADO, 2017). This research is designed to determine the factors affecting the decision to adopt open pollinated improved maize varieties, compare the mean yield of open pollinated improved with local and hybrids and to identify the major constraints in maize production in maize superzone distirct, Dang, Nepal.

\section{METHODOLOGY}

\section{Study area, sample size and data collection technique}

Dang district was purposively selected for the study taking into account that the Prime Minister Agriculture Modernization Project (PM-AMP) has selected Dang as 'maize super zone' (MOAD, 2016). The major maize growing areas of Dang- Lamahi (23 km from DADO), Satbaria (30 km from DADO), Shantinagar (30 km from DADO) and Ghorahi (where DADO is located) were identified in consultation with District Agriculture Development Office (DADO) and Maize Super zone office, Dang. Most of these areas also have been listed as the program implementation areas of Maize Super zone, PMAMP (PMAMP, 2016). From each area, samples were selected through simple random sampling in proportionate of their sampling frame. A total of 100 households were surveyed. Primary data were collected through a pre-tested interview schedule, focus group discussions and key informant interviews. Secondary data were collected from relevant publication of government offices such as Ministry of Agricultural Development (MOAD), Central Bureau of Statistics (CBS), National Planning Commission (NPC) and so on.

\section{Determination of factors affecting the decision to adopt improved maize varieties}

A probit regression model was used to analyze the effect of different variables on decision to adopt open pollinated improved maize varieties. To investigate the factors affecting the adoption of improved technology, probit model have been found to be used used in many studies (Hattam, 2006). Fadare et al. (2014) used probit regression model to study the factors affecting adoption decision of improved maize varieties in Nigeria. In a like manner, Kafle 
(2010) also used probit model to analyze the factors affecting the decision to adopt improved maize varieties in developing countries. In contrary to this, Kafle and Shah (2012) used the binary logistic regression to identify the socio-economic and farm characteristics affecting the decision in adoption of hybrid maize varieties. The probit model is often used when a choice is to be made between two alternatives; in this study, decision to either adopt (or not adopt) improved maize varieties. From the perspective of an economist, an individual $i$ makes a decision to adopt if the utility associated with that adoption choice $\left(\mathrm{V}_{1 j}\right)$ is higher than the utility associated with decision not to adopt (alternative choice), $\left(\mathrm{V}_{\mathbf{0 j}_{j}}\right)$. Koop (2003) stated that the difference in utilities of the two alternative choices is stated as $Y_{j}^{*}=V_{l j}-V_{0 j}$ and the econometric specification of the model is given in its latent as:

$Y_{j}^{*}=X_{j} \beta+e_{j}$

Where $Y_{j}^{*}$ is an unobserved (latent) random variable that defines farmer's binary (adoption) choices, $X_{j}$ are sets of explanatory variables associated with individual $j . \beta$ is a vector of coefficients associated with the explanatory variables while $e_{j}$ represents the random error terms defined as: $e \sim N(0,1)$. The relationship between the unobserved variable $Y^{*}$ and the observed outcome $(Y j)$ can be specified as:

$$
\begin{aligned}
& Y j=1, \text { if } Y j^{*} \geq 0 \\
& Y j=0, \text { if } Y j^{*<0}
\end{aligned}
$$

Probit model has the characteristic feature; the effect of independent variables on dependent variables is non-linear. It is a statistical model which aims to form a relation between probability values and explanatory variables ensuring that the probability value remains between 0 and 1. For the statistical analysis of the model, STATA software package was used.

In this study, adoption of open pollinated improved maize varieties will be based on an assumed underlying utility function. According to this theory, open pollinated improved maize varieties will be adopted by the farmer, if the utility obtained from the open pollinated improved maize varieties exceeds that non-adoption. The farmer's behaviour towards open pollinated improved maize varieties is described by the following equations;

$$
\begin{aligned}
& \operatorname{Prob}\left(\mathrm{Y}_{\mathrm{i}}^{*}\right)=\sigma_{0}+\Sigma \delta_{\mathrm{n}} \mathrm{X}_{\mathrm{i}}+\varepsilon_{\mathrm{i}} \quad \ldots \ldots \ldots \ldots \ldots \ldots . . . \ldots \text { Equation } 1
\end{aligned}
$$

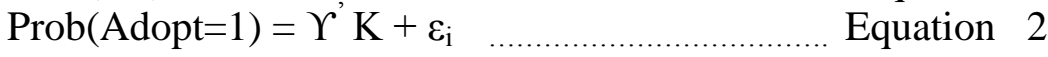

$$
\begin{aligned}
& \text { Where, }
\end{aligned}
$$

$\mathrm{Y}^{*}{ }_{\mathrm{i}}=\mathrm{A}$ latent variable representing the propensity of a farm household $\mathrm{i}$ to adopt open pollinated improved maize varieties ( 1 if farmer adopt open pollinated improved maize and 0 otherwise)

$\mathrm{X}_{\mathrm{i}}=\mathrm{K}=$ the vector of households' socio-economic and farm characteristics and variables that influence the adoption decision

$\sigma_{0}, \delta_{\mathrm{n}}=$ parameters to be estimated

$\varepsilon_{\mathrm{i}}=$ error term of the $\mathrm{i}^{\text {th }}$ farm households

$\mathrm{i}=1,2,3, \ldots \mathrm{n}$ farm households

The probit model specified in this study to analyze the factors affecting farmers' decisions to adopt open pollinated (OP) improved maize varieties

$\operatorname{Pr}$ (adopting OP improved varieties $=1)=\mathrm{f}\left(\mathrm{b}_{0}+\mathrm{b}_{1} \mathrm{X}_{1}+\mathrm{b}_{2} \mathrm{X}_{2}+\mathrm{b}_{3} \mathrm{X}_{3}+\mathrm{b}_{4} \mathrm{X}_{4}+\mathrm{b}_{5} \mathrm{X}_{5}+\right.$ $\left.\mathrm{b}_{6} \mathrm{X}_{6}+\mathrm{b}_{7} \mathrm{X}_{7}+\mathrm{b}_{8} \mathrm{X}_{8}+\mathrm{b}_{9} \mathrm{X}_{9}\right)$

where, $\mathrm{Pr}=$ Probability score of adopting OP improved varieties

$\mathrm{X}_{1}=$ Major occupation (Dummy)

$\mathrm{X}_{2}=$ Ethnicity (Dummy)

$\mathrm{X}_{3}=$ Gender of the household head (decision maker) (Dummy)

$\mathrm{X}_{4}=$ Area under open pollinated improved maize (in Ha.)

$\mathrm{X}_{5}=$ Number of visits of agricultural technician to farmer's field 
$\mathrm{X}_{6}=$ Number of visits by farmer to agrovets

DOI: http://dx.doi.org/10.3126/jmrd.v3i1.18916

$\mathrm{X}_{7}=$ Input support (dummy)

$\mathrm{X}_{8}=$ Seed_source (dummy)

$\mathrm{X}_{9}=$ Credit access (dummy)

$b_{1}, b_{2} \ldots b_{9}=$ Probit coefficient, $b_{0}=$ Regression coefficient

Table 1. Statistical description of the variables used in the probit regression model.

\begin{tabular}{|c|c|c|c|}
\hline Variables & Description & Value & $\begin{array}{l}\text { Expected } \\
\text { sign }\end{array}$ \\
\hline Major occupation & Major occupation of the household & $\begin{array}{l}\text { Agriculture }=1, \text { otherwise }=0 \\
\text { (Dummy) }\end{array}$ & + \\
\hline Ethnicity & Ethnicity of the household & $\begin{array}{l}\text { Brahmin/Chettri }=1 \text {, otherwise } \\
=0 \text { (Dummy) }\end{array}$ & $+/-$ \\
\hline $\begin{array}{l}\text { Gender of the } \\
\mathrm{HH}\end{array}$ & $\begin{array}{l}\text { Gender of the household head (decision } \\
\text { maker) }\end{array}$ & $\begin{array}{l}\text { Male }=1, \text { otherwise }=0 \\
\text { (Dummy) }\end{array}$ & $+/-$ \\
\hline $\begin{array}{l}\text { Area under OP } \\
\text { maize }\end{array}$ & $\begin{array}{l}\text { Area under open pollinated improved } \\
\text { maize }\end{array}$ & Hectare (ha) & + \\
\hline $\begin{array}{l}\text { No. of visits of } \\
\text { Ag. technician }\end{array}$ & $\begin{array}{l}\text { Number of visits of agricultural technician } \\
\text { to farmer's field }\end{array}$ & Times (in number) & + \\
\hline $\begin{array}{l}\text { No. of visits to } \\
\text { agrovet }\end{array}$ & Number of visits by farmer to agrovets & Times (in number) & $+/-$ \\
\hline Input support & Input support from anywhere & Yes $=1$, otherwise $=0$ (Dummy) & + \\
\hline Seed source & Seed source for the farmers & $\begin{array}{l}\text { DADO/cooperatives }=1, \\
\text { otherwise }=0 \text { (Dummy) }\end{array}$ & + \\
\hline Credit access & Credit access for the farmers & Yes $=1$, otherwise $=0$ (Dummy & + \\
\hline
\end{tabular}

\section{Mean comparison of productivity of local, $\mathrm{OP}$ improved and hybrid varieties}

An unpaired t test with equal variances was used to compare the productivity of OP improved and local varieties of maize. T-test was again used to compare the productivity of OP improved and hybrid varieties. Before applying $t$ test, multivariate normality test was done to check the normality of the data. Statistical packages for Social Sciences (SPSS) was used for data analysis.

\section{Problems/constraints associated with maize production}

Opinions regarding the major problems associated with maize production were asked of the respondents and ranked on the basis of their priority to different problems. Indexing/Scaling technique was applied to construct an index for prioritizing the problems as per farmers' perception using MS-Excel. Miah (1993) stated that the scaling techniques provide the direction and extremity attitude of the respondents towards any proposition. On the basis of responded frequencies, weighted indexes were calculated for the analysis of farmer's perception on the extent of production problems. Farmer's perception to the different production problems were ranked by using five point scales. The formula used to determine the index for intensity of various problems is: 
$\mathrm{I}_{\text {prob }}=\sum \frac{\text { Sifi }}{N}$

where, $\mathrm{I}_{\text {prob }}=$ index value for intensity of problem

$\sum=$ summation

$\mathrm{S}_{\mathrm{i}}=$ scale value at $\mathrm{i}^{\text {th }}$ intensity/severity

$\mathrm{f}_{\mathrm{i}}=$ frequency of the $\mathrm{i}^{\text {th }}$ severity

$\mathrm{N}=$ total no. of the respondents $=\sum \mathrm{f}_{\mathrm{i}}$

where, $\mathbf{I}_{\text {prob }}=$ index, $0<\mathrm{I}<1$

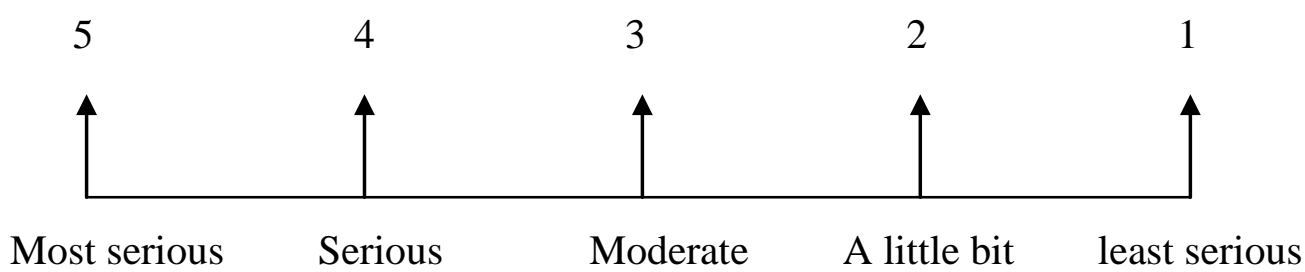

Figure 1. Scale of rating

\section{RESULTS AND DISCUSSION}

Determination of factors affecting the decision to adopt improved maize varieties

According to Rogers and Shoemaker (1971), adoption is the mental process through which an individual passes from the first stage of awareness or knowledge of an innovation to a decision to adopt or reject and then confirmation of this decision. To identify the factors affecting the decision to adopt OP improved maize varieties, a probit model of regression was used. Among the 100 respondents, the binary response was coded as; OP improved maize adopters $=1$ and 0 otherwise. The Wald test $\left(\mathrm{LR} \mathrm{chi}^{2}\right)$ for the model indicated that the model has good explanatory power at the $1 \%$ level. This means that all the explanatory variables included in the model jointly influence farmer's probability of adoption of OP improved maize varieties. The probit model estimation gave a pseudo $\mathrm{R}^{2}$ of 0.44 , which implies that the variables included in the model are able to explain about 44 percent of the probability of farmers' decisions to adopt or not to adopt OP improved maize varieties. The measure of goodness of fit here concluded that the probit model employed had integrity and hence is appropriate.

Table 2. Factors affecting the decision to adopt OP improved maize varieties.

\begin{tabular}{llllll}
\hline Variables & Coefficients & $\mathrm{P}>|\mathrm{z}|$ & $\begin{array}{l}\text { Standard } \\
\text { error }\end{array}$ & $\mathrm{dy} / \mathrm{dx}^{\mathrm{b}}$ & $\mathrm{S}^{\mathrm{b}}$ \\
\hline Major occupation (Agriculture =1) & -.4631 & 0.262 & .4126 & -.1379 & .1104 \\
Ethnicity (Brahmin/Chettri =1) & $.9454^{\mathrm{b} * *}$ & 0.007 & .3488 & .3130 & .1134 \\
Gender of the household head (male =1) & $-1.8256^{* *}$ & 0.040 & .8882 & -.3081 & .0668 \\
Area under OP maize (Ha.) & $1.8886^{* * *}$ & 0.002 & .6094 & .6086 & .1925 \\
No. of visits of Ag. technician (times in number) & .2795 & 0.151 & .1946 & .0901 & .0641 \\
Number of visits to agrovets (times in number) & $-.2766^{* *}$ & 0.045 & .1378 & -.0892 & .0444 \\
Input support (yes= 1) & .0364 & 0.926 & .3901 & .0117 & .1248 \\
Seed source (DADO/cooperatives= 1) & $1.3436^{* * *}$ & 0.000 & .3683 & .4240 & .1072 \\
Credit access (yes=1) & .2507 & 0.497 & .3690 & .0815 & .1205 \\
Constant & .4119 & 0.671 & .9692 & - & - \\
\hline
\end{tabular}

*** Significant at 1\% level ;** Significant at 5\% level ; * Significant at $10 \%$ level

${ }^{\mathrm{b}}$ Marginal change in probability evaluated at the sample means 


\begin{tabular}{lc}
\hline Summary Statistics & \\
\hline Number of observation(N) & 100 \\
Log likelihood & -36.481983 \\
LR chi $^{2}(9)$ & $56.53 * * *\left(\right.$ Prob $\left.^{2} \mathrm{chi}^{2}=0.0000\right)$ \\
Pseudo R $^{2}$ & 0.44 \\
Predicted probability (adoption) & 0.7432264 \\
\hline Goodness of fit test & Pearson $\mathrm{chi}^{2}(85)=221.90$ Prob $^{2} \mathrm{chi}^{2}=0.0000$
\end{tabular}

Source: Field survey, 2017

Probit regression analysis showed that five variables were statistically significant for the decision to adopt OP improved varieties of maize. They were; ethnicity, gender of the household head, area under improved maize, number of visits by farmer to agrovets and seed source (Table 2). For the interpretation of the model, marginal effects were driven from the regression coefficients, calculated from the partial derivatives as a marginal probability. The interpretation is shown in Table 2.

Ethnicity being Brahmin/Chettri (dummy) was found to be highly significant (at $1 \%$ level of significance) and positively related to the adoption of OP improved maize varieties. The probability of adoption of OP improved maize increases by $31 \%$ for the farmers whose ethnicity is Brahmin/Chettri as compared to the farmers having their ethnicity otherwise (Table 2). In addition, the study revealed that the majority of the farmers belong to caste Brahmin/Chettri (59\%). Also, it has been revealed that, of the total farmers having principal occupation agriculture, majority were Brahmin/Chettri (56\%). Sengupta (1970) stated that the farmers having agriculture as their primary occupation were found to be showing the higher adoption behavior. Apart from this, it has been reported that the level of adoption was higher among the farmers of intermediate castes to whom farming was a traditional occupation than among the farmers who belongs to higher ritual status (Alam, 1965).

Similarly, area under improved maize was found to be highly significant (at $1 \%$ level of significance) and positively related to the adoption of OP improved maize varieties. A unit increase in area of improved maize would increase the probability of adoption of OP improved maize varieties by $61 \%$ (Table 2). Though a unit of improved maize cultivated area is increased within a farm, it might have positive multiplier effects in adoption of improved varieties by other farms. The size of cultivated land was found to have positive and significant effect on the adoption of new agricultural technology (Gogoi \& Gogoi, 1989). In addition, Olowu et al. (1988) stated that the farmers who have large scale cultivation are willing to take risk associated with the adoption of new technology.

Unlike this, household head (decision maker) being male (dummy) was found to be significant (at 5\% level of significance) but negatively related to the adoption of OP improved maize varieties. The probability of adoption of OP improved maize varieties decreases by $31 \%$ for the households having male household head as compared to households having female household head (Table 2). Perhaps, male leaders might have focused on hybrids for higher productivity and females might have preferred improved for the reason that this year produce could be kept and used for next year seeds in a case of improved varieties; oftentimes, females shows saving nature. In a like manner, Kafle and Shah (2012) reported that the male headed household positive influences on the adoption of hybrid maize varieties than others. Aregu et al. (2011) also reported that the government has encouraged women participation and gender inclusion in the workshop and training related to seed production, nursery management and fertilizer treatments. In a like manner, Tavya et al. 
(2013) stated that it would be an encouragement to increase the agricultural productivity if technological innovation is properly understood from the gender perspective.

Furthermore, the number of visits by farmers to agrovets was found to be significant but negatively related to the adoption of OP improved maize at 5\% level of significance. A unit increase in the number of visits to agrovet decreases the probability of adoption of OP improved maize varieties by $8 \%$ (Table 2 ). This might be due to the reason that the agrovets are motivating the farmers for adopting the multinational hybrids because of the high benefits associated with the sale of those hybrids. There are 93 agrovets in Dang district. The hybrid maize varieties mostly available in the agrovets are: Rajkumar, Nutan, Pioneer 3396, Pioneer 3522, Bioseed 679, Kanchan, Subarna and Aditya (DADO, 2017). Also, it has been revealed that the private institutions such as agrovets are the prime sources of hybrid maize seeds for the farmers. Agrovet was found to be principal supplier of hybrid seeds, supplying $90.7 \%$ of the total hybrid seeds reaching to farmers (Kafle \& Shah, 2012). Lastly, seed source being DADO/cooperatives (dummy) was found to be highly significant (at $1 \%$ level of significance) and positively related to the adoption of OP improved maize varieties. For the households, seed source being DADO/cooperatives, the probability of adoption of OP improved maize varieties increases by $42 \%$ as compared to the households, seed source being otherwise (Table 2). The DADO and cooperatives might have given emphasis for the adoption of the improved varieties with the subsidy scheme given by the government of Nepal. Also, the study revealed that the majority of the farmers of the study area buy seeds from DADO/cooperatives (53\%). And of them, nearly $85 \%$ of the farmers have cultivated seeds of improved maize varieties in their field. It has been reported that $17 \mathrm{Mt}$. seeds of open pollinated improved maize varieties was sold from DADO, Dang with $50 \%$ subsidy in the fiscal year 2016/17 (DADO, 2017). Besides, DADO is the authorized government agricultural institution having the clear mandate of providing extension services to the farmers. Kafle (2000) revealed that that there exists a positive influence of extension contact on adoption of improved maize varieties.

\section{Mean comparison of productivity of OP improved and local varieties}

Multivariate normality test showed that the two samples are normally distributed (DoornikHansen chi2 $(4)=0.835$, Prob $>$ chi $2=0.9336)$. Two-sample $t$ test with equal variances was carried out to compare the productivity means. The mean productivity of OP improved maize varieties $(2.28 \mathrm{t} / \mathrm{ha}$ ) in Dang was found to be significantly higher (at $1 \%$ level of significance) compared to local varieties (1.74 t/ha) (Table 3). It would be a wise decision to substitute the local varieties by improved ones for higher productivity. Paudyal (2001) reported that the trend of cultivating local varieties has decreased in the mid hills of Nepal. In a like manner, Lamichhane et al. (2015) revealed that the improved varieties (Rampur composite, Arun 2, Manakamana 6) are getting popularity in the western hills; this indicated the positive attitude of maize growing farmers in adopting the improved varieties substituting the local.

Table 3. Mean comparison of productivity of OP improved and local variety.

\begin{tabular}{llllll}
\hline Variables & Obs & Mean & Std. Err. & Std. Dev. & t value \\
\hline Productivity of OP improved & 68 & 2.2846 & 0.0530 & 0.4369 & $4.5994^{* * *}$ \\
varieties & & & & & 0.2800 \\
Productivity of local varieties & 15 & 1.7413 & 0.0723 & 0.4621 & \\
Combined & 83 & 2.1864 & 0.0507 & \\
Diff & & 0.5432 & 0.1181 & & Source: Field Survey, 2017
\end{tabular}

Moreover, government should bring a policy giving aggressive subsidy in inputs (seeds and fertilizers) allied with access to technology and training to the farmers in adoption of 
improved maize varieties. No doubt, this could substitute the local varieties to a greater extent in terms of area coverage which ultimately leads to increased productivity and adoption.

\section{Mean comparison of productivity of hybrid and OP improved maize varieties}

Test for multivariate normality was carried out to check whether the two samples are normally distributed or not. This normality test showed that the two samples are normally distributed (Doornik-Hansen chi2 $(4)=0.592$, Prob $>$ chi $2=0.9640$ ). Two-sample t test with equal variances was again used to compare the productivity means. The mean productivity of hybrid maize varieties (3.81 t/ha) in Dang was found to be significantly higher (at $1 \%$ level of significance) compared to OP improved varieties (2.28 t/ha) (Table 4). National Maize Research Program (NMRP) should orient their efforts in developing the high yielding hybrids to increase the maize productivity in Nepal. In addition, appropriate extension services are needed for the adoption of developed hybrids. Timsina et al. (2016) also used two independent samples t- test to compare the yield of maize in Kavre and Lamjung districts of Nepal, which revealed that the productivity of maize was significantly higher in kavre (4.63 t/ha) compared to Lamjung (3.2 t/ha). In addition, the average yield of maize (both hybrid and open pollinated improved improved varieties) in Kavre was calculated $4.63 \mathrm{t} / \mathrm{ha}$, while the average yield of only hybrid varieties was calculated $5.06 \mathrm{t} / \mathrm{ha}$; this showed the superiority of hybrids over improved in terms of yield. Also, the yield of hybrid maize was found to be significantly higher in Kavre (4.63 t/ha) compared to Lamjung (3.2 t/ha).

Table 4. Mean comparison of productivity of hybrid and OP improved variety.

\begin{tabular}{llllll}
\hline Variables & Obs & Mean & Std. Err. & Std. Dev. & t value \\
\hline $\begin{array}{l}\text { Productivity of hybrid } \\
\text { varieties }\end{array}$ & 17 & 3.8112 & 0.2643 & 1.0899 & $9.0965^{* * *}$ \\
$\begin{array}{l}\text { Productivity of OP improved } \\
\text { varieties }\end{array}$ & 68 & 2.2846 & 0.0530 & 0.4369 \\
$\begin{array}{l}\text { Combined } \\
\text { Diff }\end{array}$ & 85 & 2.5899 & 0.0943 & 0.8694 \\
\hline$* *$ Significant at 1\% level & & 1.5266 & 0.1678 & & \\
& & & Source: Field Survey, 2017
\end{tabular}

\section{Assessment of problems/constraints associated with the maize production}

From the survey conducted among the maize growers, lack of availability of quality seeds and fertilizers was ranked as the major problem followed by lack of advanced technology and training, when questioned about the problems associated with the maize production. Similarly, lack of proper interaction between farmers and extension service providers, infestation of disease and pest and lack of proper irrigation and drainage facilities were the third, fourth and fifth problems respectively as per farmer's ranking (Table 5). Paudyal (2001); Shrestha and Timsina (2011) also stated that the yield is significantly affected by seed quality, infestation of disease and pest and availability of irrigation. Similarly, Hailu (1992) stated that the lack of availability of quality seeds including other inputs (fertilizers, farm machinery) are the main bottlenecks in increasing maize production and productivity. In addition, Rogers (2003) and Hintze et al. (2003) reported that the adoption of maize seed production, increment in maize production and income are assisted by the availability of technical assistance and adequate irrigation facilities.

Farmers should be provided the environment for interaction and discussion on various problems related to crop production. It has been revealed that the farmers who have joined the Farmer's Field School (FFS) were more forward in identification and prioritization of the problems and solutions themselves (Adhikari, 2005). 
DOI: http://dx.doi.org/10.3126/jmrd.v3i1.18916

Table 5. Problems associated with the maize production.

\begin{tabular}{|c|c|c|c|c|c|c|c|c|}
\hline S. N & Problems & $\begin{array}{l}\text { Most } \\
\text { serious }\end{array}$ & Serious & Moderate & $\begin{array}{l}\text { A little } \\
\text { bit }\end{array}$ & Least & $\begin{array}{l}\text { Index } \\
\text { value }\end{array}$ & Rank \\
\hline 1 & $\begin{array}{l}\text { Lack of quality seeds and } \\
\text { fertilizers }\end{array}$ & 54 & 31 & 4 & 11 & 0 & 0.86 & $\mathrm{I}$ \\
\hline 2 & $\begin{array}{l}\text { Lack of advanced } \\
\text { technology and training }\end{array}$ & 20 & 47 & 22 & 7 & 4 & 0.74 & II \\
\hline 3 & $\begin{array}{l}\text { Lack of proper interaction } \\
\text { between farmers and } \\
\text { extension service providers }\end{array}$ & 18 & 13 & 45 & 22 & 2 & 0.65 & III \\
\hline 4 & $\begin{array}{l}\text { Incidence of diseases and } \\
\text { insects pests }\end{array}$ & 8 & 1 & 12 & 51 & 28 & 0.42 & IV \\
\hline 5 & $\begin{array}{l}\text { Lack of proper irrigation } \\
\text { and drainage }\end{array}$ & 0 & 7 & 18 & 9 & 66 & 0.33 & V \\
\hline
\end{tabular}

Source: Field Survey, 2017

\section{CONCLUSION}

Adoption of the OP improved maize varieties could be promoted by mobilizing the innovative female adopters in the community. Agrovets might be motivating the farmers for adopting multinational companies' hybrids; this might be due to either realization of high benefits in selling those hybrids or due to the unavailability of subsidy seeds of OP improved maize varieties. Government should give dealership to the registered agrovets with easy procedure for selling the subsidy seeds of OP improved maize varieties. The productivity of OP improved maize varieties in Dang was found to be significantly higher than local maize varieties. Ministry of Agricultural Development should bring a policy giving aggressive subsidy in inputs to the farmers in adoption of OP improved maize varieties; this could substitute the local varieties to a greater extent in terms of area coverage which ultimately leads to increased adoption. Also, there is a need of high yielding hybrid maize varieties to be developed, released and made available in Nepal. Moreover, the difference between the productivity of OP improved and hybrid maize varieties was found to be highly significant in this study which concluded that hybrids are significantly superior to OP improved varieties in terms of productivity. National Maize Research Program (NMRP) should orient their efforts in developing the high yielding hybrid varieties in Nepal to increase the maize productivity. In addition, appropriate extension services are needed for the adoption of developed hybrids. Lacking proper access to quality seeds, advanced technology and training, effective extension services, appropriate plant protection measures, irrigation and drainage were identified as the major problems associated with the maize production ranked from first to fifth priority respectively; an efficient action plan need to be formulated which could orient towards increased maize production and productivity in maize super zone district- Dang and ultimately Nepal.

\section{ACKNOWLEDGEMENTS}

This research was fully funded by Nepal Agricultural Research Council, Socio-economics and Agricultural Research Policy Division (SARPOD), Khumaltar, Nepal.

\section{AUTHORS' CONTRIBUTION}

S. S. designed the research methodology, analyzed data and wrote the paper in consultation with Y.N. G. and D. D. assisted S. S. in questionnaire design, conducting field survey, data 
collection and data entry. S. S. revised the article for the final approval of the version to be published.

\section{CONFLICTS OF INTEREST}

The authors declare that there is no conflict of interest.

\section{REFERENCES}

Adhikari, K.P. (2005). Effectiveness of IPM technology through farmer's field school on vegetable production in Nawalparasi and Kavrepalanchowk districts of Nepal. M.Sc. Thesis, Institute of Agriculture and Animal Science, Tribhuvan University, Rampur, Chitwan, Nepal. 93p.

Alam, Md. O. (1965). Characteristics of progressive farmers. Indian Journal of Adult Education, 25, 96-97.

Aregu, L., Puskur, R., \& Sambrook, C.B. (2011). The role of gender in crop value chain in Ethiopia.

DADO. (2017). Annual report. District Agricultural Development Office, Dang, Nepal.

Fadare, O. A., Akerele, D., \& Toritseju, B. (2014). Factors Influencing Adoption Decisions of Maize Farmers in Nigeria. International Journal of Food and Agricultural Economics, 2(3),45-54.Retrievedfrom http://www.foodandagriculturejournal.com/vol2.no3.pp45.pdf

Gogoi, S.K. and Gogoi, D.K. (1989). Adoption of recommended plant protection practices in Rice: a Multivariate Analysis. Indian Journal of Extension Education, 25, $26-29$.

Hailu, G. (1992). Availability and use of seed in Ethiopia. Program support unit, Canadian International Development Agency, Addis Ababa, Ethiopia.

Hattam, B.C. (2006). Barriers to the adoption of organic agriculture: An investigation using the Theory of planned behaviour (p.2006).

Hintze, L.H., Renkow, M., \& Sain, G. (2003). Variety characteristics and maize adoption in Honduras. Journal of Agricultural Economics, 29, 307-317.

Kafle, B. (2010). Determinants of Adoption of Improved Maize Varieties in Developing Countries: a Review. International Research Journal of Applied and Basic Sciences, 1(1), 1-7. https://doi.org/10.1111/j.1477-9552.2004.tb00115.x

Kafle, B., \& Shah, P. (2012). Hybrid or Open Pollinated Maize Varieties ? a SocioEconomic Assessment of Nepalese Farmers' Experiences, 11(4), 211-220.

Koop, G. (2003). Bayesian Econometrics. Chichester, UK: John Wiley \& Sons Ltd.

Lamichhane, J., Timsina, K.P., Ranabhat, D.B. \& Adhikari, S. (2015). Technology adoption analysis of improved maize technology in western hills of Nepal. Journal of Maize Research and Development, 1, 146-152.

Miah, A.Q. (1993). Applied statistics: A course handbook for human settlements planning. Asian Institute of Technology, Division of Human Settlements Development, Bangkok, Thailand. $412 \mathrm{p}$.

MOAD. (2016). Prime Minister Agriculture Modernization Project (PMAMP) Final Cabinet Document. Ministry of Agricultural Development, Government of Nepal, Singhadarbar, Kathmandu, Nepal.

MOAD. (2017). Statistical Information on Nepalese Agriculture 2015/2016. Agri Statistics Section, Monitoring, Evaluation and Statistics Division, Ministry of Agricultural Development, Singha Durbar, Kathmandu, Nepal.

Olowu, T.A., Iloka, A.I., \& Ekpere, J.A. (1988). Farmers' characteristics and adoption of improved cassava varieties. Indian Journal of Extension Education 22, 21-26. 
Paudyal, K.R., Ransom, J.K., Rajbhandari, N.P., Adhikari, K., Gerpacio, R.P., \& Pingali, P.L. (2001). Maize in Nepal: Production Systems, Constraints, and Priorities for Research. Kathmandu: NARC and CIMMYT.

Rogers, E.M. (2003). Diffusion of Innovations (Fourth Edition). New York: Free Press.

Rogers, E.M., \& Shoemaker, F.F. (1971). Communication of innovations (Second Edition). New York: Free Press. 256 p.

Sengupta, T. (1970). Main occupation: A variable for adoption. Indian Journal of Extension Education 6: 75-76.

Shrestha, J., \& Timsina, K.P. (2011). Agronomic Performance and Economic Analysis of Maize (Zea mays L.) under Different Plant Geometry and Nitrogen Rates in Chitwan, Nepal. Nepalese Journal of Agriculture Science, 9, 5-13.

Tavya, S., Abdelali-Martini, M., Aw-Hassan, A. Rischkowsky, B., Tibbo, M., \& Rizvi, J. (2013) Gender Roles in Agriculture: The Case of Afghanistan. Indian Journal of Gender Studies, 20(1), 111-134. doi: 10.1177/0971521512465939

Timsina, K.P., Ghimire, Y.N., \& Lamichane, J. (2016). Maize production in mid hills of Nepal: from food to feed security. Journal of Maize Research and Development, 2 (1): 20-29, doi: http://dx.doi.org/10.3126/jmrd.v2i1.16212 